\title{
THE APPLICATION OF HYDROGELS BASED ON N-ISOPROPYLACRYLAMIDE AND ANIONIC COMONOMERS
}

\author{
Aleksandar S. Zdravkovićc ${ }^{\star}$, Ljubiša B. Nikolić², Snežana S. Ilić-Stojanović², \\ Vesna D. Nikolić ${ }^{2}$ \\ ${ }^{1}$ Vocational High School for Technology and Art, Leskovac, Serbia \\ (REVIEW PAPER) \\ UDC 678.7:628.3:504.5 \\ 2University of Niš, Faculty of Technology, Leskovac, Serbia
}

Hydrogels represent three-dimensional networks of polymer chains that have the ability of absorption of a significant amount of water or biological fluid. A special group of hydrogels are copolymers which respond to changes of $\mathrm{pH}$ values and temperature. Desirable characteristics of temperature- and $\mathrm{pH}$-sensitive hydrogels based on $\mathrm{N}$-isopropylacrylamide and anionic comonomers for different applications, from pharmaceutical to the environmental one, can be designed by composition of copolymers. The presence of the amide and carboxyl group in the structure of these hydrogels enables their application as adsorbents in the processes of removing the pollutants from aqueous solutions. Hydrogels based on $\mathrm{N}$-isopropylacrylamide and anionic comonomers represent desirable three-dimensional matrices for controlled and sustained release of agrochemicals and drugs in relation to temperature and $\mathrm{pH}$ of the surrounding medium. Hydrogels, as separation devices, perform the concentrating of compounds or microorganisms solutions by absorption of greater amounts of water. One more application of these copolymers is for immobilization of enzymes.

Keywords: hydrogel, adsorption, pollutants, agrochemicals, separation, controlled delivery

\section{Introduction}

Hydrogels are hydrophilic functional polymer materials with a specific three-dimensional cross-linked structure composed from polymer chains joined in crosslinking points. They are composed from chemically or physically crosslinked polymers in the way that they can absorb and retain a great amount of water within their threedimensional network without dissolving [1-3]. In 1960, the investigations of hydrogels began with a landmark paper on poly(hydroxyethylmethacrylate) [4]. Polymer chains of hydrogels are connected to each other, and the nature of their crosslinking can be physical or chemical. Polymer chains of physically crosslinked hydrogels are connected by electrostatic forces, hydrogen bonds or hydrophobic interactions. Polymer chains of chemically crosslinked hydrogels are connected by covalent bonds. According to the origin of monomers, they can be natural, synthetic and the combination of both natural and synthetic types. Hydrogels can be obtained from natural polymers or they can be synthetized from hydrophilic monomers. Hydrogels obtained from natural polymers are biocompatible and biodegradable, but they do not possess good mechanical properties and they can contain pathogens. Synthetic hydrogels have a defined structure which can be designed in order to reach desirable properties $[5,6]$.

In recent years, the researchers' attention has been drawn to temperature- and $\mathrm{pH}$-sensitive synthetic hydrogels based on $\mathrm{N}$-isopropylacrylamide (NIPAM) and anionic comonomers (acrylic acid (AA), methacrylic acid
(MAA), itaconic acid (IA), maleic acid (MA) and crotonic acid (CA)) for various applications: environmental [7-9], biological [10], pharmaceutical [11], biomedical [12] and the concentration of solutions [13]. The presence of ionizing groups in their structure enables better absorption of the solution and their application as adsorbents for the removal of heavy metals, dyes and radioactive elements $[8,9]$. The most important advantages of their application are the ability to regenerate, which is accomplished by adding acids, the possibility of adsorption in a wide range of $\mathrm{pH}$ values and time of contact with an adsorbate until the equilibrium has been reached [14]. The environmental application of copolymer hydrogels based on NIPAM and anionic comonomers, in addition to the removal of the pollutants, is reflected in controlling the release of agrochemicals: pesticides and fertilizers. Copolymers represent the delivery systems which protect agrochemicals from degradation, prevent contamination of the soil and surface water due to runoff from the arable land [15-17]. The characteristics of absorption and superabsorption of hydrogels can be used for concentrating the solutions of different compounds and microorganisms, i.e. their separation from aqueous solutions $[18,19]$. Superabsorbent materials are hydrogels with the possibility of water absorption from 10 to a few thousands greater than their weight in a dry state $\left(10-1000 \mathrm{~g} / \mathrm{g}_{\text {xerogels }}\right)[20,21]$. According to some authors, a hydrogel which absorbs the amount of water or biological fluid 100 times greater than the xerogels weight has superabsorbent character-

\footnotetext{
* Author address: Aleksandar Zdravković, Vocational High School for Technology and Art,

Vilema Pušmana 17, 16000 Leskovac, Serbia

E-mail: zdravkovic.aleksandar87@gmail.com

The manuscript received: April, 11, 2017.

Paper accepted: May, 17, 2017.
} 
istics [22]. Dual responsive hydrogels represent desirable matrices for drug delivery $[11,12,23]$. However, in physiological conditions $\left(36^{\circ} \mathrm{C} ; \mathrm{pH}=7.4\right)$, copolymers based on NIPAM and anionic comonomers can lose their sensitivity to temperature changes. This problem can be overcome by adding a triggering agent (a compound with hydrophobic nature) or decreasing the $\mathrm{pH}$ values (if the drug delivery takes place in the environment with lower $\mathrm{pH})[11,12]$. Copolymer hydrogels are used for immobilization of the enzymes by the copolymerization method with the solution of this biological catalyst [10].

The aim of this paper is the review of potential applications of hydrogels based on NIPAM and anionic comonomers as adsorbent materials for the removal of pollutants, as systems for delivery drugs or agrochemicals, and devices for compound separation as well. In addition to these, the methods of synthesis of copolymer hydrogels and characteristics of the obtained products will be discussed.

Temperature- and $\mathrm{pH}$-sensitive hydrogels based on NIPAM and anionic comonomers

Hydrogels are very often divided according to the type of external stimuli to which they respond, such as: $\mathrm{pH}$, temperature, pressure, ionic strength, electrical impulses, ultrasound, magnetic field, light, the presence of biomolecules and their combination. They can be divided into neutral and ionic hydrogels based on the polarity of side groups. Reversible hydrogels sensitive to external stimuli are the ones for which changes are reversible in relation to the changes of the external stimulus $[1,24,25]$

Thermo-sensitive hydrogels can swell or contract due to changes in the temperature of the surrounding fluid because of the presence of hydrophilic monomers such as NIPAM, pluronic, methylcellulose, $N$-vinylcaprolactam and tetronic [2]. Poly( $N$-isopropylacrylamide), p(NIPAM), is known as a typical thermo-sensitive polymer which shows a lower critical solution temperature (LCST) at about $32{ }^{\circ} \mathrm{C}$ in water [26]. One of the examples of negatively thermo-sensitive hydrogels represents its copolymer poly( $N$-isopropylacrylamide-co-2-hydroxypropyl methacrylate), p(NIPAM/HPMet) $[5,6,27]$.

$\mathrm{pH}$-sensitive hydrogels possess ionizing side groups, and small changes in $\mathrm{pH}$ values of the medium can lead to significant changes in the swelling degree. In the aqueous medium, side groups ionize and electrostatic repulsive forces appear between polymer chains. Their appearance causes the increase of the distance between nodes of network and the increase of absorption and the sweeling degree. According to the nature of side groups, hydrogels can be anionic, cationic and amphiphilic $[25,28,29]$.

Hydrogels based on NIPAM and anionic comonomers (AA, MAA, IA, MA and CA) can be synthetized by emulsion polymerisation [9], dispersion polymerisation [30], free radical polymerization in the solution [12,31] with cross-linker $N, N^{\prime}$-methylene-bis(acrylamide) (BIS) and $\gamma$-rays polymerization [32,33]. Chemical structures of NIPAM and anionic comonomers are shown in Figure 1.

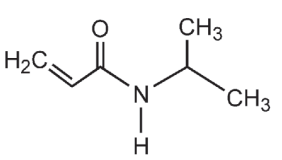

$N$-isopropylacrylamide<smiles>C=C(CC(=O)O)C(=O)O</smiles>

Itaconic acid

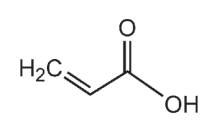

Acrylic acid<smiles>O=C(O)/C=C/C(=O)O</smiles>

Maleic acid

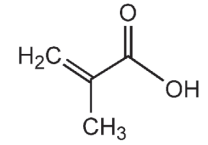

Methacrylic acid<smiles>C/C=C/C(=O)O</smiles>

Crotonic acid
Figure 1. Chemical structure of NIPAM monomer and anionic comonomers AA, MAA, IA, MA and CA

The influence of the temperature change $\left(18-49^{\circ} \mathrm{C}\right)$ on hydrogels based on NIPAM and MAA, synthesized with a different content of monomers using cross-linker tetraethylene glycol dimethyl acrylate (TEGDMA), has been investigated. Temperature sensitivity of poly $(\mathrm{N}$ isopropylacrylamide-co-methacrylic acid) copolymer, $\mathrm{p}$ (NIPAM/MAA), with the molar content of NIPAM up to $70 \%$ is very mild. Greater sensitivity is noticed with a higher molar content of NIPAM monomer in the structure of $p$ (NIPAM/MAA) copolymer [34].

In the research of Zdravković et al., superabsorbent hydrogels of poly( $N$-isopropylacrylamide-co-acrylic acid), $\mathrm{p}(\mathrm{NIPAM} / \mathrm{AA})$, have been synthetized by radical polymerization with ethylene glycol dimethacrylate (EGDM) as a cross-linker. Hydrogels have showed $\mathrm{pH}$ sensitivity. The increase of $\mathrm{pH}$ value of the solution from 2.2 to 6.8 at $25{ }^{\circ} \mathrm{C}$ led to the increase of the equilibrium swelling degree of hydrogel with $10 \mathrm{~mol} \%$ AA and $1.5 \mathrm{~mol} \%$ EGDM from 8.3 to 259.8 [35]. The swelling of ionic hydrogel depends primarily on the ionic groups content (the acidic and/or basic), their degree of ionization, $\mathrm{pH}$ value, the ionic strength of the surrounding media, valence and nature of the counterion and of the swelling medium composition. Hydrophilicity of the polymer network increases with the increase of the ionic groups content in the hydrogel structure, which causes a higher swelling degree. This group of hydrogels (polyampholyte) is characterized by a high swelling degree just because of the ion group ionization, which depends on the pK values and ions hydration. Amphiphilic hydrogels swell significantly in the solutions with low or high $\mathrm{pH}$ values [36,37]. In hydrogels based on NIPAM and anionic comonomer, the increases of $\mathrm{pH}$ values above $\mathrm{pKa}$ of ionic monomer lead to a higher degree of ionization of carboxyl groups (COO-). Electrostatic repulsive forces that appeared between carboxyl anions have caused the expanding of the polymer network and greater absorption of water or biological fluid. In the highly acidic environment, carboxyl groups are protonated which decreases the capacity of hydrogels absorption $[11,12,38,39]$. Superabsorbent hydrogels can be used for the disposable diapers production and as soil conditioners $[39,40]$.

Improving the sensitivity of poly( $N$-isopropylacrylamide-co-itaconic acid) hydrogel, $\mathrm{p}$ (NIPAM/IA), $\mathrm{pH}$ and 
temperature changes can be reached by adding $\mathrm{NaCl}$ during the copolymerization reaction in the solution but up to a certain limit (up to $0.2 \mathrm{~g}$ of $\mathrm{NaCl}$ on $0.5 \mathrm{~g}$ of $\mathrm{NI}-$ PAM and $0.015 \mathrm{~g}$ of IA in $8 \mathrm{~mL}$ of water). Besides the mentioned salt, characteristics of swelling are also influenced by temperature and $\mathrm{pH}$ value of the surrounding fluid. The maximum swelling degree in distilled water (161.3) is reached for the hydrogel sample where $0.2 \mathrm{~g}$ of $\mathrm{NaCl}$ is added into the starting reaction mixture [31].

UV photopolymerization method in the solution was used for obtaining $\mathrm{p}$ (NIPAM/MAA) hydrogel with the biodegradable cross-linker, poly(ethylene glycol)-co-poly( $\varepsilon$ caprolactone) (PEG-Co-PCL) macromer. Hydrolytic degradation of $\mathrm{p}$ (NIPAM/MAA) copolymer at $\mathrm{pH} 7.4$ occurred by breaking up the labile ester bonds. With the increase of the MAA content in hydrogel, hydrolytic degradation of the polymer was increased. This effect was the result of degradation of ester bonds of the PCL segment due to the exposure to a higher amount of water in the swollen gel. Higher absorption and expanding of the polymer network were the results of a higher number of ionizing carboxyl groups (COO-) at $\mathrm{pH} 7.4$ between which the electrostatic interactions appeared. After 6 weeks of simulated physiological conditions, a significant loss of weight of hydrogel appeared [38].

Removal of pollutants by adsorption

By discharging the effluents from textile industries and nuclear power plants, the production of electrical cables, batteries, ores, steel and electrical TVs, the wastewater is contaminated by heavy metals, dyes and radioactive elements [41-43]. Heavy metals are toxic for living organisms and they show the properties of bioaccumulation and non-biodegradability [44-46]. Also, dyes express toxic effects on humans and aquatic organisms. The consequence of dyed water is restriction of photosynthesis in plants $[47,48]$. The exposure to radiation of radioactive elements can cause cancer in living organisms [49]. Adsorption by hydrogels is a selective and efficient process for the removal of heavy metals, dyes and radioactive elements $[8,32,50]$. The adsorption process of pollutants from aqueous solutions by hydrogels can be schematically shown in Figure 2.

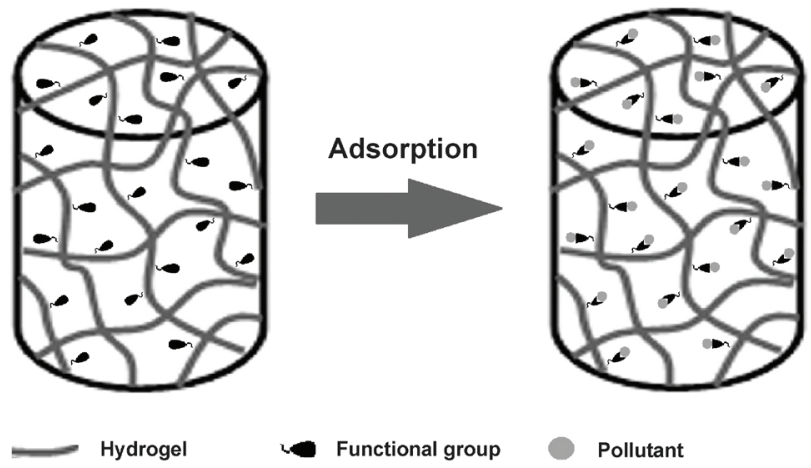

Figure 2. Schematic review of pollutant adsorption from aqueous solutions
Removal of heavy metals and radioactive elements

High adsorption capacities, simplicity of application, as well as the ability for regeneration make hydrogels suitable adsorbent materials for the heavy metals removal [51]. Regeneration, i.e. desorption of metals in temperature- and $\mathrm{pH}$-sensitive copolymer hydrogels is performed by temperature or $\mathrm{pH}$ changes (by using nitric or hydrochloric acid) $[50,52,53]$. Hydrogels which contain one or more electron donor atoms (N, S, O and $\mathrm{P})$ can form coordinate bonds with metal ions (chelates) [54].

In Table 1, the review of hydrogels based on NIPAM and anionic comonomers used for the removal of heavy metals and radioactive or rare earth elements from solutions by adsorption is shown.

Table 1. Hydrogels based on NIPAM and anionic comonomers which are used as adsorbents for the removal of heavy metals, radioactive and rare earth elements.

\begin{tabular}{cccc}
\hline Hydrogel & Adsorbate & Adsorption capacity $(\mathbf{m g} / \mathbf{g})$ & References \\
\hline $\mathrm{p}(\mathrm{NIPAM} / \mathrm{AA})$ & $\mathrm{Cu}^{2+}$ & 58.95 & {$[9]$} \\
$\mathrm{p}(\mathrm{NIPAM} / \mathrm{MAA})$ & $\mathrm{Cu}^{2+}$ & $0.765^{*}$ & {$[56]$} \\
$\mathrm{p}(\mathrm{NIPAM})$ & $\mathrm{Pb}^{2+}$ & $\approx 120$ & {$[52]$} \\
$\mathrm{p}(\mathrm{NIPAM})$ & $\mathrm{Cu}^{2+}$ & $\approx 0.015^{*}$ & {$[58]$} \\
$\mathrm{p}(\mathrm{NIPAM} / \mathrm{MA})$ & $\mathrm{UO}^{2+}$ & 94.8 & {$[32]$} \\
$\mathrm{p}(\mathrm{NIPAM} / \mathrm{A})$ & $\mathrm{Cs}^{+}$ & $\approx 120$ & {$[60]$} \\
$\mathrm{p}(\mathrm{NIPAM})$ & $\mathrm{In}^{3+}$ & $0.854^{*}$ & {$[59]$} \\
\hline${ }^{*} \mathrm{mmol} / \mathrm{g}$ & & &
\end{tabular}

In $\mathrm{p}$ (NIPAM) hydrogels, the process of heavy metals adsorption depends on temperature changes, the so-called temperature-swing (TS) technique [55]. In the work of Ju et al., p(NIPAM) was used as an adsorbent material which can easily adsorb $\mathrm{Pb}^{2+}$ ions in temperatures below LCST of homopolymers. The adsorption capacity of homopolymer hydrogel for $\mathrm{Pb}^{2+}$ ions was investigated in the temperature range of $23-50{ }^{\circ} \mathrm{C}$, where the maximum capacity was reached at $23^{\circ} \mathrm{C}$, at about $120 \mathrm{mg} / \mathrm{g}$ (Table 1). By increasing the temperature above LCST, desorption of $\mathrm{Pb}^{2+}$ ions with $\mathrm{p}$ (NIPAM) hydrogel appeared [52]. Amino and amide groups of acrylamide in hydrogels represent adsorption places for heavy metals [55].

$\mathrm{Cu}^{2+}$ ion was removed from the solution as well, by $\mathrm{p}$ (NIPAM/AA) hydrogel and micro/nano particles of $\mathrm{p}$ (NIPAM/MAA) copolymer. The mechanism of $\mathrm{Cu}^{2+}$ ion adsorption occurred by chelation with the carboxyl group of $A A$, i.e. MAA, and one copper cation complexed with two functional groups $[9,56]$. The synthetized $p$ (NIPAM/ AA) hydrogel in the work of Chen et al. was applied in polymer-enhanced ultrafiltration (PEUF) for the removal of $\mathrm{Cu}^{2+}$ ion. Retaining the $\mathrm{Cu}^{2+}$ ion and hydrogel complex on the cellulose acetate membrane was more favourable at the temperature lower than $40^{\circ} \mathrm{C}$ and $\mathrm{pH}=5$. It was concluded that environmental factors, temperature and $\mathrm{pH}$, have influence on the adsorption process of $\mathrm{Cu}^{2+}$ ion on $p($ NIPAM/AA) hydrogel [57].

Besides a classical technique of adsorption, there is the so-called solid-phase extraction (SPE) which occurs in many phases. Metal ion is complexed with an extract- 
ant in the aqueous solution, and then the complex of metal and extractant is adsorbed on temperature-sensitive hydrogels at the temperature above LCST. Between the metal-extractant complex and hydrogels, such as $\mathrm{p}$ (NIPAM), hydrophobic interactions were reached. Sodium N-dodecylbenzensulfonate (SDBS), N-dodecylbenzensulfonic acid (DBS) and $N$-octyl phosphate (OP) were used as extractants. By temperature change, the process of adsorption could be controlled, i.e. desorption of the metal and surfactant complex $[58,59]$, which at the same time represents the TS adsorption technique. The advantage of the SPE technique in comparison to the conventional extraction by solvent is cost-effectiveness and use of the lower volume of a solvent [58]. TS and SPE techniques for adsorption of heavy metals or radioactive elements are schematically shown in Figure 3.

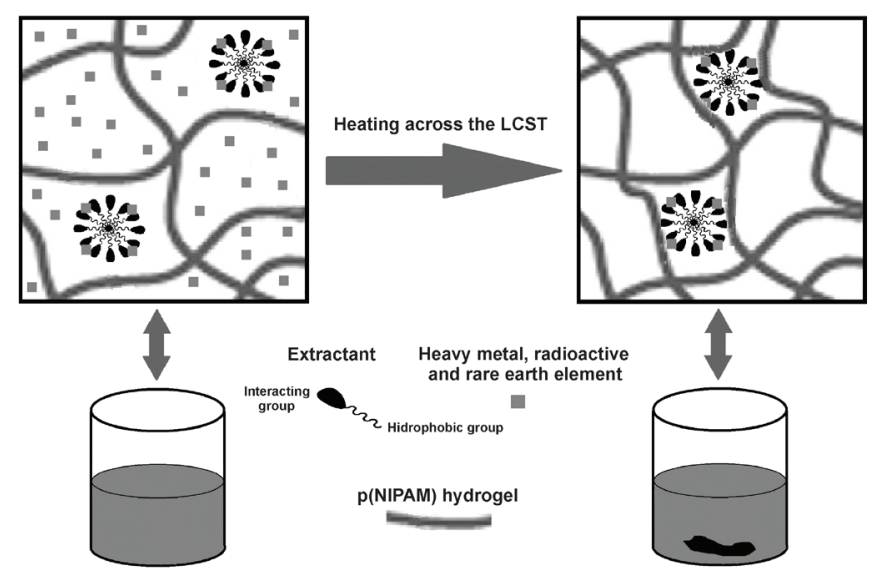

Figure 3. Schematic review of TS and SPE techniques for adsorption of heavy metals or radioactive and rare earth elements

By SPE and TS technique, $\mathrm{Cu}^{2+}$ ions were adsorbed on homopolymer $p$ (NIPAM) in the presence of SDBS and DBS surfactants. On p(NIPAM) hydrogel, a higher amount of $\mathrm{Cu}^{2+}$ ions was adsorbed in the form of the complex with SDBS by hydrophobic interactions, about $0.015 \mathrm{mmol} / \mathrm{g}$ (Table 1), at the concentrations ratio $\mathrm{CuCl}_{2} / \mathrm{SDBS}, 0.2 / 1 \mathrm{~mol} / \mathrm{dm}^{3}$ [58]. The same researchers tested the possibility of application of the SPE technique for the adsorption of rare earth element indium (In) on $p$ (NIPAM) hydrogel in the presence of extractant OP. The adsorption efficiency of $\mathrm{In}^{3+}$ ions from aqueous solution was almost 90\% [59]. Poly( $\mathrm{N}$-isopropylacrylamideco-maleic acid), $\mathrm{p}(\mathrm{NIPAM} / \mathrm{MA})$, and $\mathrm{p}(\mathrm{NIPAM} / \mathrm{IA})$ hydrogels were good adsorbent materials for the removal of $\mathrm{UO}_{2}{ }^{2+}$ and $\mathrm{Cs}^{+}$ions [32,60]. Increasing the content of MA in $\mathrm{p}$ (NIPAM/MA) hydrogel leads to the adsorption of a higher amount of $\mathrm{UO}_{2}{ }^{2+}$ ions, which can indicate that carboxyl group of MA is an interacting group for a heavy metal [32].

\section{Adsorption of dyes}

Dyes can be classified on the basis of the chemical structure and application. In regards to the application, dyes can be classified into acid, reactive, direct, dis- persive, base (cationic), vat, mordant (fixative), sulphur, metal complex and azoic dyes [61]. Cationic dyes were investigated mostly as a model substance for the adsorption process on temperature- and $\mathrm{pH}$-sensitive hydrogels based on NIPAM and anionic comonomers [8,62].

Conventional methods proved to be unsuitable for purification of wastewater contaminated by dyes due to cost-effectiveness of the process and production of secondary effluents [62,63]. The advantage of the adsorption of dyes as a method reflects in high efficiency and easiness of using [63]. The adsorption of cationic dyes on active carbon and other sorbent materials is not optimal therefore, the investigators' attention has been directed towards hydrogels $[61,62]$. Hydrogels are more suitable adsorbents because of their regeneration feature, designing of desired physico-chemical properties in the synthesis, the introduction of appropriate ligands in the structure, as well as the preparation of the composite with natural materials [64-71]. One of the example of obtaining hydrogels with adequate physical-chemical properties, sensitivity to external stimuli or selectivity, for the adsorption process of dyes, is the synthesis of $p$ (NIPAM/ MA) copolymer by $\mathrm{Y}$ radiation [72].

The comparison of adsorption characteristics of hydrogels based on NIPAM and anionic comonomers for the removal of dyes is shown in Table 2.

Table 2. The comparison of adsorption characteristics hydrogels based on NIPAM and anionic comonomers for the removal of dyes from aqueous solutions

\begin{tabular}{cccc}
\hline Hydrogel & Adsorbate & Adsorption capacity $(\mathbf{m g} / \mathbf{g})$ & References \\
\hline p(NIPAM/IA) & Brilliant Green & 228 & {$[8]$} \\
p(NIPAM/IA) & Safranine T & 207 & {$[8]$} \\
p(NIPAM/IA) & Brilliant Cresyl Blue & 204 & {$[8]$} \\
p(NIPAM/IA) & Methylene blue & 17.67 & {$[68]$} \\
p(NIPAM/MA) & Methylene blue & 322.6 & {$[72]$} \\
p(AM/AA) & Remazol Red 3BS & 44.19 & {$[73]$} \\
p(MAA) $(0 \%)^{*}$ & Basic yellow 28 & 65.8 & {$[76]$} \\
p(MAA) (80\%)* & Basic yellow 28 & 77.2 & {$[76]$} \\
p(NIPAM) & Methylene blue & 8.95 & {$[68]$} \\
${ }^{*}$ neutralization degree of monomer & &
\end{tabular}

Temperature- and $\mathrm{pH}$-sensitive $\mathrm{p}(\mathrm{NIPAM} / \mathrm{IA})$ hydrogel was used for the removal of dyes Brilliant Green, Safranine T and Brilliant Cresyl Blue. Adsorption capacities of $p$ (NIPAM/ IA) hydrogel for dyes were higher than $200 \mathrm{mg} / \mathrm{g}$ (Table 2). With increasing the number of carboxyl groups, i.e. the content of IA sodium salt in the structure of $p$ (NIPAM/IA) copolymer led to the increase of adsorption capacities for dyes Brilliant Green, Safranine T and Brilliant Cresyl Blue. It has been thought that the adsorption of cationic dyes on temperature- and $\mathrm{pH}$-sensitive hydrogels is the result of electrostatic interactions and exchange of electrons between dyes and adsorbent [8]. A significantly lower adsorption capacity of $p$ (NIPAM/IA) hydrogel for cationic dye (Methylene blue) was obtained in the work of Taşdelen et al. (Table 2). The investigators tested the adsorption capacities of $p$ (NIPAM) homopolymer and composite of $\mathrm{p}$ (NIPAM/IA) copolymer with pumice. The highest capacity for the removal was shown by the composite, $22.62 \mathrm{mg} / \mathrm{g}$. By introducing pumice into the structure of hydrogel, the number of negative adsorption 
places increased and the possibility of the ion exchange and interaction between adsorbent and adsorbate as well [68].

Copolymer based on NIPAM and MA showed a high removal capacity of the dye Methylene blue, $322.6 \mathrm{mg} / \mathrm{g}$. The content of MA in the structure of copolymer had influence on the adsorption capacity of $p$ (NIPAM/MA) hydrogel for Methylene blue [72]. So, in the case of poly(acrylamide-co-acrylic acid) copolymer, $p(A M / A A)$, the increase of anionic comonomer content showed the rise in the adsorption capacity of hydrogels for cationic dyes, Safranine-O and Magenta [62]. In the research of Corona-Rivera et al., $\mathrm{p}(\mathrm{AM} / \mathrm{AA})$ hydrogel was used for the dye Remazol Red 3BS, and a maximum adsorption capacity was obtained for hydrogel with $1 \%$ BIS as a cross-linker, $44.19 \mathrm{mg} / \mathrm{g}$ (Table 2) [73].

In the research of Fradj et al., interactive mechanisms of polyelectrolytes poly(acrylic acid), p(AA), and dyes Methylene blue and Toluidine blue were investigated and the influence of salts and surfactants on formed complexes of dyes and hydrogels as well [74]. Two kinds of interactions have appeared between polyelectrolytes and dyes: hydrophobic and electrostatic [75]. Anionic adsorption places of $p(A A)$ hydrogel were responsible for complexation of positive cationic dyes, and interactions were mostly electrostatic. The influence of surfactant cetylpyridinium chloride and $\mathrm{NaCl}$ was negative, i.e. the addition of these compounds caused destabilization of the dye and hydrogel complex [74].

Besides homopolymer based on AA, poly(methacrylic acid) homopolymer, $\mathrm{p}(\mathrm{MAA})$, was applied for the removal of the dye Basic yellow 28. P(MAA) homopolymer with the $80 \%$ neutralization degree of monomers showed better adsorption characteristics for the dye, $77.2 \mathrm{mg} / \mathrm{g}$, in comparison to hydrogel with the $0 \%$ neutralization degree of monomers, $65.8 \mathrm{mg} / \mathrm{g}$ (Table 2). The sorption mechanism of hydrogels with the $0 \%$ neutralization degree of monomers is physisorption, whereas in hydrogels with the neutralization degree of $80 \%$, both physisorption and chemisorption occur [76].

Aggregates of $p($ NIPAM/AA) microgels obtained by polymerization in the presence of BIS as a cross-linker, can efficiently remove the dye Orange II from water, even $73.1 \%$. The capacity of dyes removal by microgels aggregate depends on temperature, the concentration of cross-linker and a number of cycles of heating and cooling [77]. Parasuraman et al. investigated adsorption capacities of the same $\mathrm{p}(\mathrm{NIPAM} / \mathrm{AA})$ microgels in the unaggregated state for the same dye, where the capacity for the removal of Orange II was $56.6 \%$ at the higher temperature [78]. Figure 4 schematically shows the removal of Orange II by microgels and aggregated $p(N I P A M / A A)$ microgels. The reuse of $p(N I P A M / A A)$ microgels and their aggregates was reached by the methanol extraction, where a slight decrease of extraction efficiency appeared with the increased number of recycling cycles [71].

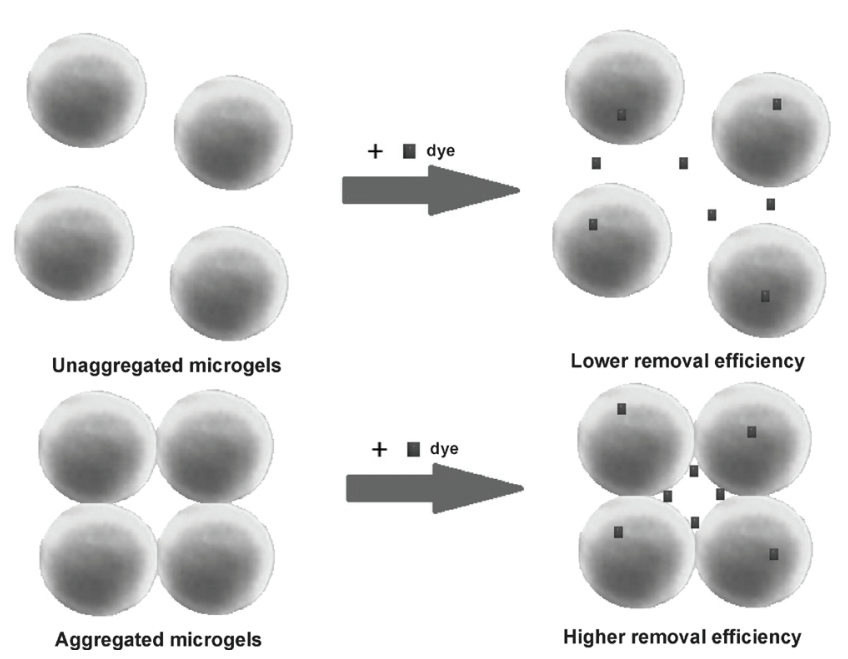

Figure 4. Schematic review of dyes removal by unaggregated and aggregated $p($ NIPAM/AA) microgels

Composites of hydrogels with natural materials such as kaolin clay [67], montmorillonite clay [70] and zeolite [69] were used for the removal of dyes from aqueous solutions, i.e. wastewater. The composite of $p(A A)$ and kaolin clay, $\mathrm{p}(\mathrm{AA})-\mathrm{K}$, was synthesized by conventional polymerization and ultrasound induced polymerization. The composite $\mathrm{p}(\mathrm{AA})-\mathrm{K}$ obtained by ultrasound had a greater adsorption efficiency of the dye Brilliant Green, because during polymerization the kaolin clay was uniformly dispersed into the matrix of $p(A A)$ hydrogel, the consequence of which was the increase of adsorption capacities of the composite [67]. In the work of Aref et al., nanocomposite of poly(acrylamide-co-maleic acid) hydrogel, $\mathrm{p}(\mathrm{AM} / \mathrm{MA})$, and montmorillonite clay synthetized in situ polymerization was used for the removal of Crystal violet from aqueous solutions [70]. Hydrophobic ZSM5 and hydrophilic $A$ zeolite were used for the synthesis of $\mathrm{p}(\mathrm{MAA})$ based composite by free radical polymerization at higher temperature $\left(80^{\circ} \mathrm{C}\right)$. Composite with $30 \mathrm{wt} \%$ of hydrophilic $\mathrm{A}$ zeolite reached higher adsorption capacity for the dye Basic yellow 28, $180 \mathrm{mg} / \mathrm{g}$. The process of the dye removal depends significantly on swelling of the composite based on $p(M A A)$ and zeolite [69].

By controlling the temperature and $\mathrm{pH}$ values, the degradation of the previously adsorbed dye on the composite of hydrogels with encapsulated titan dioxide by UV radiation could be reached. P(NIPAM/AA) hydrogel with encapsulated $2.5 \mu \mathrm{m}$ titan dioxide at $\mathrm{pH}=4,20$ or $30^{\circ} \mathrm{C}$ and UV radiation time of $25 \mathrm{~min}$, the degradation degree of Methyl orange of $55.6 \%$ could be reached. The photocatalytic activity of the composite after the fifth reusing was still good, and a degree of dye degradation was above $75 \%$ [79].

Adsorption characteristics of hydrogels sensitive to $\mathrm{pH}$ and temperature changes were used for the removal of antibiotic ciprofloxacin from aqueous solution [80].

Hydrogels have found their application in the removal of nutrient from water [81-83] which, in higher concentrations, can lead to eutrophication of aqueous bodies, 
the excessive growth of algae. Compounds of nitrogen and phosphor, i.e. nitrites $\left(\mathrm{NO}_{2}^{-}\right)$, nitrates $\left(\mathrm{NO}_{3}^{-}\right)$and orthophosphates $\left(\mathrm{PO}_{4}{ }^{3-}\right)$ are considered under the term nutrient. The consequence of eutrophication is a decrease of dissolved oxygen, which has a negative effect on ecosystem and can cause the death of fish species [14,84].

\section{Controlled release of agrochemicals}

Hydrogels are widely used as the agrochemical delivery system for a controlled and sustained release of pesticides and fertilizers [85]. By conventional application of pesticides and fertilizers, the surface water is contaminated due to runoff from an arable land. By using the systems based on hydrogels for a controlled release of active components, the dose is decreased and the time for the application of agrochemicals is increased. These systems disable the degradation of agrochemicals by light, air, humidity, microorganisms and evaporation [15-17]. Besides the application for the controlled release of agrochemicals, hydrogels can be used for retaining water in the soil (soil conditioners) with the aim of providing water for the plants growth [86].

The systems for the controlled release of pesticides or fertilizers based on hydrogels can be produced in two ways. The first method includes the synthesis of hydrogel and then, afterwards, loading the hydrogel with an active component by absorption from aqueous solutions $[15,16]$. In the second method, hydrogel is synthesized in the solution of an active component [86-88]. Different factors can affect the loading of hydrogels with pesticides and fertilizers as active components: the initial concentration of agrochemicals, porosity of hydrogel and absorption time [15].

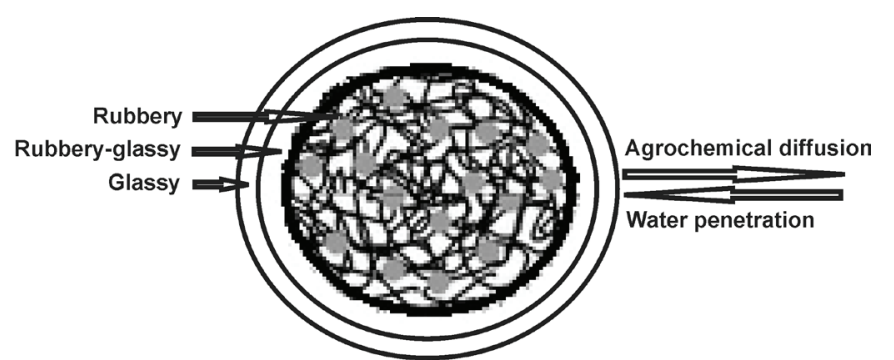

Figure 5. Schematic review of agrochemical release from polymer by water penetration

In investigations of Saraydin et al., hydrogels based on $\mathrm{AM}$ and $\mathrm{CA}$, i.e. IA, were used as carriers for the controlled release of a pesticide sodium 2,2 dichloropropionate (dalapon) and fertilizers ammonium nitrate $\left(\mathrm{NH}_{4} \mathrm{NO}_{3}\right)$, potassium nitrate $\left(\mathrm{KNO}_{3}\right)$ and ammonium sulphate $\left(\left(\mathrm{NH}_{4}\right)_{2} \mathrm{SO}_{4}\right)$. Hydrogels are synthesized by the method of radiation copolymerization (source ${ }^{60} \mathrm{Co}$ ) along with the aqueous solution of agrochemicals. Hydrogels poly(acrylamide-co-itaconic acid), $p(A M / / A)$, and poly(acrylamide-co-crotonic acid), $p(A M / C A)$, with loaded agrochemicals represent the systems for release which is controlled by swelling. Pesticides or fertilizers are uniformly dispersed within a glassy polymer matrix. Immersion of polymers into water leads to water penetration into the matrix and swelling of the copolymer which enables diffusion of the active component to the outside [87-89]. Figure 5 schematically shows the process of releasing the agrochemical by swelling.

Hydrogels based on AM and IA, i.e. CA, obtained by radiation induced polymerization are suitable as carriers for the release of dalapon, ammonium nitrate, potassium nitrate and ammonium sulphate. The controlled release of pesticides and fertilizers can be reached by varying the content of IA and CA comonomers and dose of radiation as well $[87,88]$. The release rate of agrochemicals from the matrix of hydrogel depends on the percentage of loading of an active component [15].

Another type of system for slow release of agrochemicals was synthesized by free radical polymerization of AA monomer with BIS as a cross-linker in the presence of liquid fertilizers. The release of two liquid formulations of fertilizers was investigated: (1) LFA mixture of monoand dipotassium phosphates, urea and demineralized water (LF-A) (2) mixture of mono- and dibasic potassium and ammonium phosphates, urea and demineralized water (LF-B). The release rate of liquid formulation LF-B from hydrogel matrix at room temperature was lower due to a higher content of ionic groups which interacted with phosphates salts. The crosslinking degree had the influence on the release of fertilizers formulation, and with the increase of the crosslinking degree, the swelling degree of $\mathrm{p}(\mathrm{AA})$ hydrogel decreased and therefore the release rate of agrochemicals [86].

The system for agrochemicals delivery can be based on natural and synthetic polymers. Thus, for the controlled and sustained release of a fungicide thiram, the system based on p(MAA) and starch was used. At the beginning, the release of fungicide increased and then, after a certain time, the agrochemical was released in a controlled way. The synthetized hydrogel with a higher concentration of BIS as a cross-linker enabled the sustained release of thiram [16].

Composites with $\mathrm{p}(\mathrm{AA})$ hydrogel and wheat straw, i.e. lignin, were applied for the release of urea and pesticides $[90,91]$. In the work of Sun et al., p(AA) hydrogel and its composite with lignin was synthetized for its application for the cumulative release of pesticides paraquat, cyfluthrin and cyhalofop-butyl. Grafting of lignin on $p(A A)$ network enabled the higher capacity of water absorption for different $\mathrm{pH}$ values. $\mathrm{p}(\mathrm{AA})$ hydrogel reached lower capacity of loading of pesticides and a cumulative release rate $(50.06-68.42 \%)$ in comparison to the composite (84.27-91.23\%) for 10 days [90].

\section{Separation of compounds}

Temperature- and $\mathrm{pH}$-sensitive hydrogels have application as devices for separation, i.e. concentrating of aqueous solutions of different compounds [13,18,92,93]. The advantage of hydrogels for compounds separation is the possibility for its own regeneration [93]. 
In the work of Cai et al., concentrating of lignin was performed by $p$ (NIPAM) and $p$ (NIPAM/AA) hydrogels. A significantly higher separation degree of hydrolytic lignin was obtained for ionic hydrogel, $p$ (NIPAM/AA), which can be explained by the fact that it came to ionic repulsion between lignin and hydrophilic AA groups in the structure of hydrogel. In the case of p(NIPAM) application as a device for lignin separation, the adsorption of lignin appeared on the hydrogel itself. The efficiency of the lignin separation depended on the time of the process. Concentrating of lignin by $p($ NIPAM/AA) hydrogels was increased in the first few hours and maximal separation could be reached for $5 \mathrm{~h}$. With every next cycle of using, $p($ NIPAM/AA) copolymer showed higher separation efficiency $(\eta)$ of lignin (Indulin AT), the values for separation in percentages for the first and third cycle were 40.9 and $85.2 \%$, respectively [18].

Copolymer based on NIPAM and AA was used for the separation of poly(ethylene oxide) (PEO) and dextran blue (DB) compounds in aqueous solutions. The separation efficiency of DB and PEO can be controlled by the degree of hydrogel crosslinking, the initial concentration of the compound and molecular mass (for PEO). Maximal concentrating of DB was obtained for the lowest concentration of DB $\left(0.25 \mathrm{~g} / \mathrm{dm}^{3}\right)$ and the highest concentration of a cross-linker ( $1 \mathrm{~mol} \% \mathrm{BIS}), \eta=0.98$. Concentrating of $\mathrm{PEO}$ was the highest at the higher initial concentration of PEO $\left(1 \mathrm{~g} / \mathrm{dm}^{3}\right)$ and cross-linker $(1 \mathrm{~mol} \%$ $\mathrm{BIS})$, and a higher molecular mass of the compound for the separation as well $(1700 \mathrm{~kg} / \mathrm{mol}), \eta=0.99$ [13].

Figure 6 schematically shows the application of hydrogels for the process of concentrating of different compounds.

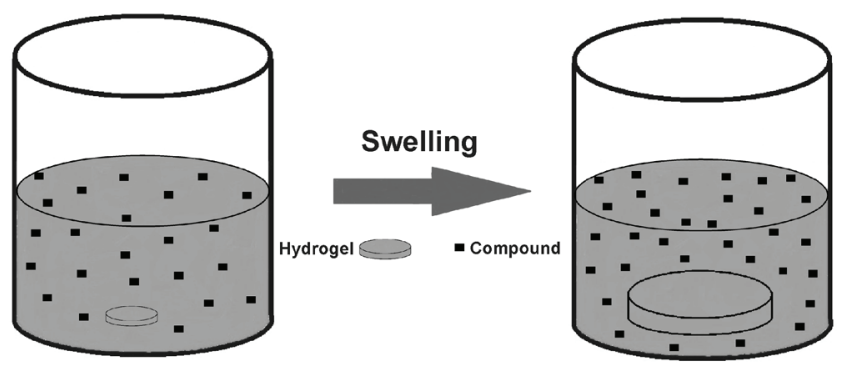

Figure 6. Schematic review of concentrating different compounds by hydrogels

Temperature- and $\mathrm{pH}$-sensitive hydrogels have advantages for separating bio-products due to mild conditions during concentrating and preventing their denaturation in comparison to conventional methods. One more advantage is the cost-effectiveness of the process since hydrogels, i.e. polymers, are cheaper than ion exchangers. During the process of separation, a hydrogel absorbs water and compounds of a small molecular mass, whereas proteins are not absorbed but concentrated in the solution [92,93]. Non-ionic p(NIPAM) hydrogel had good separation characteristics during a greater cycle of using for the concentration of cellulase enzymes, pro- duced by the fermentation of the fungus Trichoderma reesei RUT C-30 [93]. A hydrogel sensitive to $\mathrm{pH}$ changes synthetized from polyacrylamide, $p(A M)$, and carboxymethyl cellulose by the grafting method in the work of Mohy Eldin et al. was applied with the aim of concentrating bovine serum albumin (BSA) [92].

Microorganisms can be also concentrated by the application of hydrogels based on AM and anionic comonomers. Millimetre sized beads of superabsorbent $p(A M /$ IA) copolymer represent the material which can be used for concentrating of microorganisms: Escherichia coli and bacteriophage MS2 [19].

\section{Other aplication}

The application of hydrogels for the development of modern drugs is significant because of the possibility for designing the desirable properties. Potential use of hydrogels based on NIPAM was investigated for the modified release of drugs, e.g. paracetamol, phenacetine, ibuprofen, naproxen and piroxicam [94-96]. The synthesis of hydrogels with the minimal content of residual reactants is a necessary condition for human application [94].

Hydrogels based on NIPAM and anionic comonomers are applied as carriers for drugs delivery [97], materials for immobilization of enzymes [10,98] and sorbents for protein isolation [30].

The percentage of loading a drug and the mechanism of its release from the temperature- and $\mathrm{pH}$-sensitive hydrogel can be regulated by the hydrogel content itself, i.e. the content of the $\mathrm{pH}$ sensitive component (IA, AA, MA) and cross-linker. The system for delivery of paracetamol was obtained by copolymerization of AM and IA monomers with the use of BIS as a cross-linker. A lower degree of crosslinking and a higher content of IA provided the fastest release of the paracetamol drug [23] The increase of the content of a $\mathrm{pH}$-sensitive component in biodegradable $\mathrm{p}$ (NIPAM/MAA) hydrogel, synthetized by PEG-co-PC macromolecular cross-linker at $\mathrm{pH} 7.4$, caused a higher rate of releasing the BSA [38].

Dual responsive $p$ (NIPAM/MAA) and $p$ (NIPAM/MA) hydrogels represent self-regulated drug delivery systems. At physiological temperature and $\mathrm{pH}$, these hydrogels lose sensitivity to temperature and therefore the application for the drug delivery is harder. Electrostatic interactions of carboxyl anions of MAA or MA part of the structure of copolymers with hydrophobic compounds of positive charging (triggering agent), diphenhydramine, lidocaine, metoclopramide and propranolol, enabled the temperature sensitivity of copolymer and its collapse at physiological temperature. The $\mathrm{pH}$-sensitive component is a 'biosensor' whereas the drug delivery is done by the temperature-sensitive hydrogel. As a triggering agent, protons $\left(\mathrm{H}^{+}\right)$can be used, i.e. the $\mathrm{pH}$ change of the environment from the physiological $\mathrm{pH}$ value $(\mathrm{pH}=7.4)$ to weak acidic conditions ( $\mathrm{pH}=5.7)$. Microgels of $\mathrm{p}(\mathrm{NIPAM} /$ MAA) and $p($ NIPAM/MA) copolymers, previously loaded with the drug have the possibility of application in tumour 
therapy [11,12].

In the work of Milašinović et al., the immobilization of the lipase enzyme from Candida rugosa by p(NIPAM/ IA) and $p$ (NIPAM) hydrogels was investigated. Polymerization of hydrogels was performed in the presence of lipase enzyme. Copolymer hydrogel proved to be better for immobilization of the enzyme, which is ascribed to its polyelectrolyte structure. The increase of the IA content in the structure of hydrogels increased the activity of the immobilized enzyme; the optimal sample is with $10 \mathrm{~mol} \%$ IA [10]. With the immobilization by hydrogel, the enzyme was protected from negative environmental factors. The sufficient size of the pores of hydrogel should be provided so that molecules of the substrate and products of the reaction can penetrate. Further in their research, the investigators came to the conclusion that the addition of surface active matters during the synthesis of p(NIPAM/ IA) copolymer does not have any influences on the activity of lipase enzymes $[10,98]$.

As an adsorbent, $p($ NIPAM/AA) hydrogel isolates hemoglobin from the human blood. The isolation of protein is mostly based on electrostatic, hydrophobic and hydrogen interactions with hydrogel. Electrostatic interactions appear between carboxylate anions (COO-) of hydrogel and a positively charged protein. By $p$ (NIPAM/ $\mathrm{AA}$ ) hydrogel at $\mathrm{pH}=6$, the efficiency of hemoglobin sorption of $93 \%$ can be reached [30].

Synthetized macroporous crosslinked copolymers of poly(methyl methacrylate-co-acrylamide), p(MMA/AM), with free volume of open pores from 50 to $90 \%$, are not dissolved and do not swell in organic solvents, in contrast to usual crosslinked copolymers which become porous after swelling. If the obtained copolymer has open pores, it can be used for immobilization of microorganisms or enzymes within pores and as the initial material for obtaining ion exchanger resin, or as an adsorbent $[99,100]$.

Dual $\mathrm{pH}$ - and temperature-sensitive antibacterial nanocomposite Ag-poly( $\mathrm{N}$-isopropylacrylamide-co-itaconic acid), Ag-p(NIPAM/IA) was investigated. By introducing a small amount of itaconic acid, IA, the capacity of swelling and phase transition temperature of $p(N I P A M / I A)$ copolymer increased. Nanocomposite Ag-p(NIPAM/IA) hydrogels show good antibacterial potential [101].

\section{Conclusion}

Hydrogels based on NIPAM and anionic comonomer (AA, MAA, IA, MA and CA) can be synthetized by different methods of polymerization: emulsion polymerization, dispersion polymerization, precipitation polymerization, free radical polymerization in the solution and UV and $\mathrm{Y}$-rays induced polymerization. The content of $\mathrm{pH}$-sensitive component, an anionic comonomer, has a synergistic effect on the swelling degree of hydrogels and the adsorption of pollutants from aqueous solutions. Interacting groups of copolymer for the adsorption of pollutants are amide groups of NIPAM and carboxyl groups of an anionic comonomer. Hydrogels show sensitivity to surrounding stimuli, $\mathrm{pH}$ and temperature, and therefore, their application as systems for the controlled release of drug or agrochemicals. There are two ways of the preparation of the NIPAM and anionic comonomer based systems for the controlled release of pesticides or fertilizers. The first way is absorption of the aqueous solution of agrochemical by the previously synthetised copolymer, and the second one is when the synthesis occurs in the presence of the aqueous solution of agrochemical. Immobilization of enzymes by hydrogels is possible and it is performed by copolymerization of monomers with the addition of enzymes (the same as for agrochemicals, the second way). Concentrating the aqueous solutions of different compounds and microorganisms by hydrogels is based on the absorption characteristics of temperature- and $\mathrm{pH}$-sensitive copolymers. General conclusion is that hydrogels based on NIPAM and anionic comonomers, depending on the composition, represent matrix systems for a wide range of applications: biomedical, biological, pharmaceutical, the environmental one, and as devices for separation.

\section{Acknowledgements}

This work is part of the project MNTR TR-34012 financed by the Ministry of Education, Science and Technological Development of the Republic of Serbia. The authors are grateful for the support provided by the Ministry.

Abbreviations and symbols

Lower critical solution temperature - LCST

$\mathrm{N}$-isopropylacrylamide - NIPAM

Acrylic acid - AA

Methacrylic acid - MAA

Itaconic acid - IA

Maleic acid - MA

Crotonic acid - CA

Poly $(N$-isopropylacrylamide) - $p$ (NIPAM)

Poly(N-isopropylacrylamide-co-2-hydroxypropyl methacrylate) - p(NIPAM/HPMet)

Poly(N-isopropylacrylamide-co-acrylic acid) - p(NIPAM/

AA)

Poly( $N$-isopropylacrylamide-co-methacrylic acid) $\mathrm{p}($ NIPAM/MAA)

Poly(N-isopropylacrylamide-co-itaconic acid) - p(NIPAM/

IA)

Poly $(N$-isopropylacrylamide-co-maleic acid) - p(NIPAM/

MA)

Poly(acrylamide-co-acrylic acid) - p(AM/AA)

Poly(acrylamide-co-maleic acid) hydrogel - $p(A M / M A)$

Poly(acrylamide-co-itaconic acid) - p(AM/IA)

Poly(acrylamide-co-crotonic acid) - $p(A M / C A)$

Poly(methyl methacrylate-co-acrylamide) - $p(M M A / A M)$

Poly(acrylic acid) - $p(A A)$

Poly(methacrylic acid) - $p$ (MAA)

Poly(acrylamide) - $p(A M)$ 
Composite of $p(A A)$ and kaolin clay - $p(A A)-K$

Ag-poly( $N$-isopropylacrylamide-co-itaconic acid) - Agp(NIPAM/IA)

Poly(ethylene glycol)-co-poly(E-caprolactone) - PEG-co-PCL $N, N$ '-methylene-bis(acrylamide) - BIS

Tetraethylene glycol dimethyl acrylate - TEGDMA

Ethylene glycol dimethacrylate - EGDM

Temperature-swing - TS

Polymer-enhanced ultrafiltration - PEUF

Solid-phase extraction - SPE

Sodium $N$-dodecylbenzensulfonate - SDBS

$\mathrm{N}$-dodecylbenzensulfonic acid - DBS

$\mathrm{N}$-octyl phosphate - OP

Poly(ethylene oxide) - PEO

Dextran blue - DB

Bovine serum albumin - BSA

\section{References}

[1] S. S. Ilić-Stojanović, L. B. Nikolić, V. D. Nikolić, S. D. Petrović, in Novel Approaches for Drug Delivery, R. K. Keservani, A. K. Sharma, R. K. Kesharwani Ed., IGI Global, Hershey, USA, 2016, p. 278.

[2] N. A. Peppas, P. Bures, W. Leobandung, H. Ichikawa, Hydrogels in pharmaceutical formulations. European Journal of Pharmaceutics and Biopharmaceutics, 50(1) (2000) 27-46.

[3] M. Ebara, Y. Kotsuchibashi, R. Narain, N. Idota, Y. J. Kim, J. M. Hoffman, K. Uto, T. Aoyagi, in Smart Biomaterials, Springer Japan, Tokyo, 2014, p. 9.

[4] O. Wichterle, D. Lim, Hydrophilic gels for biological use, Nature, 185 (1960) 117-118.

[5] S. Ilić-Stojanović, L. Nikolić, V. Nikolić, I. Ristić, J. Budinski-Simendić, A. Kapor, G. M. Nikolić, The structure characterisation of thermosensitive poly $(\mathrm{N}$ isopropylacrylamide-co-2-hydroxypropyl methacrylate) hydrogel, Polymer International, 63(6) (2014) 973-981.

[6] S. Ilić-Stojanović, Synthesis and characterization of negatively thermosensitive hydrogels, LAP LAMBERT Academic Publishing, Akademikeverlag GmbH \& Co. KG, Saarbrücken, Germany, 2015, p. 80.

[7] D. Saraydin, E. Karadağ, O. Güven, The releases of agrochemicals from radiation induced acrylamide/crotonic acid hydrogels, Polymer Bulletin, 41(5) (1998) 577-584.

[8] B. Özkahraman, I. Acar, S. Emik, Removal of cationic dyes from aqueous solutions with poly ( $\mathrm{N}$-isopropylacrylamideco-itaconic acid) hydrogels, Polymer Bulletin, 66(4) (2011) $551-570$

[9] J. J. Chen, A. L. Ahmad, B. S. Ooi, Poly(Nisopropylacrylamide-co-acrylic acid) hydrogels for copper ion adsorption: Equilibrium isotherms, kinetic and thermodynamic studies, Journal of Environmental Chemical Engineering, 1(3) (2013) 339-348.

[10] N. Milašinović, N. Milosavljević, J. Filipović, Z. KneževićJugović, M. Kalagasidis Krušić, Synthesis, characterization and application of poly( $\mathrm{N}$-isopropylacrylamide-co-itaconic acid) hydrogels as supports for lipase immobilization, Reactive and Functional Polymers, 70(10) (2010) 807814.

[11] M. Constantin, S. Bucatariu, V. Harabagiu, I. Popescu, P. Ascenzi, G. Fundueanu, Poly(N-isopropylacrylamide-comethacrylic acid) $\mathrm{pH} /$ thermo-responsive porous hydrogels as self-regulated drug delivery system, European Journal of Pharmaceutical Sciences, 62 (2014) 86-95.

[12] G. Fundueanu, M. Constantin, S. Bucatariu, P. Ascenzi, $\mathrm{pH} /$ thermo-responsive poly( $\mathrm{N}$-isopropylacrylamide-comaleic acid) hydrogel with a sensor and an actuator for biomedical applications, Polymer, 110 (2017) 177-186.

[13] S. Champ, W. Xue, M. B. Huglin, Concentrating aqueous solutions of water soluble polymers by thermoreversible swelling of poly[( $\mathrm{N}$-isopropylacrylamide)-co-(acrylic acid)] hydrogels, Macromolecular Chemistry and Physics, 201(9) (2000) 931-940.

[14] Y. Zheng, A. Wang, Superadsorbent with threedimensional networks: From bulk hydrogel to granular hydrogel, European Polymer Journal, 72 (2015) 661-686.

[15] H. L. Abd El-Mohdy, Water sorption behavior of CMC/ PAM hydrogels prepared by $\mathrm{y}$-irradiation and release of potassium nitrate as agrochemical, Reactive and Functional Polymers, 67(10) (2007) 1094-1102.

[16] B. Singh, D. K. Sharma, A. Gupta, In vitro release dynamics of thiram fungicide from starch and poly(methacrylic acid)based hydrogels, Journal of Hazardous Materials, 154(1 3) (2008) 278-286.

[17] W. E. Rudzinski, A. M. Dave, U. H. Vaishnav, S. G. Kumbar, A. R. Kulkarni, T. M. Aminabhavi, Hydrogels as controlled release devices in agriculture, Designed Monomers and Polymers, 5(1) (2002) 39-65.

[18] W. Cai, E. C. Anderson, R. B. Gupta, Separation of Lignin from Aqueous Mixtures by Ionic and Nonionic Temperature-Sensitive Hydrogels, Industrial and Engineering Chemistry Research, 40(10) (2001) 22832288.

[19] X. Xie, J. Bahnemann, S. Wang, Y. Yang, M. R. Hoffmann, "Nanofiltration" Enabled by Super- Absorbent Polymer Beads for Concentrating Microorganisms in Water Samples, Scientific Reports, 6 (2016) 20516.

[20] C. Mayur, K. Senthilkumaran, G. Hemant, Super porous hydrogels: a recent advancement in gastroretentive drug delivery system, Indonesian Journal of Pharmacy, 24(2) (2013) 1-13.

[21] M. J. Zohuriaan-Mehr, K. Kabiri, Superabsorbent Polymer Materials: A Review, Iranian Polymer Journal,17(6) (2008) 451-477.

[22] B. H. Cipriano, S. J. Banik, R. Sharma, D. Rumore, W. Hwang, R. M. Briber, S. R. Raghavan, Superabsorbent Hydrogels That Are Robust and Highly Stretchable, Macromolecules, 47(13) (2014) 4445-4452.

[23] M. Stanojević, M. Kalagasidis Krušić, J. Filipović, J. Parojčić, M. Stupar, An investigation into the influence of hydrogel composition on swelling behavior and drug release from poly(acrylamide-co-itaconic acid) hydrogels in various media, Drug Delivery, 13(1) (2006) 1-7.

[24] M. C. Koetting, J. T. Peters, S. D. Steichen, N. A. Peppas,. Stimulus-responsive hydrogels: Theory, modern advances, and applications, Materials Science and Engineering: R: Reports, 93 (2015) 1-49.

[25] N. A. Peppas, Physiologically responsive gels, Journal of Bioactive and Compatible Polymers, 6(3) (1991) 241-246.

[26] M. Heskins, J. E. Guillet, Solution Properties of Poly(Nisopropylacrylamide), Journal of Macromolecular Science, Part A - Chemistry, 2(8) (1968) 1441-1455.

[27] S. S. Ilić-Stojanović, L. B. Nikolić, V. D. Nikolić, S. D. Petrović, A. S. Zdravković, J. V. Stamenković, The effect of cross-linker content on the swelling properties of intelligent gels, Advanced technologies, 3(2) (2014) 10-15. 
[28] A. Kumar, A. Srivastava, I. Y. Galaev, B. Mattiasson, Smart polymers: physical forms and bioengineering applications, Progress in Polymer Science, 32(10) (2007) 1205-1237.

[29] B. Jeong, A. Gutowska, Lessons from nature: stimuli responsive polymers and their biomedical applications, Trends in Biotechnology, 20(7) (2002) 305-311.

[30] X. Chen, S. Chen, J. Wang, A pH-responsive poly(Nisopropylacrylamide-co-acrylic acid) hydrogel for the selective isolation of hemoglobin from human blood, Analyst, 135(7) (2010) 1736-1741.

[31] Y. Ling, M. Lu, Thermo and $\mathrm{pH}$ dual responsive Poly ( $\mathrm{N}$-isopropylacrylamide-co-itaconic acid) hydrogels prepared in aqueous $\mathrm{NaCl}$ solutions and their characterization, Journal of Polymer Research, 16(1) (2009) 29-37.

[32] E. Kam, B. Taşdelen, A. E. Osmanlioglu, Uranyl ion uptake capacity of poly ( $\mathrm{N}$-isopropylacrylamide/maleic acid) copolymeric hydrogels prepared by gamma rays Radiation Physics and Chemistry, 81(6) (2012) 618-621.

[33] Y. Pei, J. Chen, L. Yang, L. Shi, Q. Tao, B. Hui, J. Li, The effect of $\mathrm{pH}$ on the LCST of poly(N-isopropylacrylamide) and poly(N-isopropylacrylamide-co-acrylic acid), Journal of Biomaterials Science, Polymer Edition, 15(5) (2004) 585-594.

[34] A. Prior-Cabanillas, I. Quijada-Garrido, G. Frutos, J. M. Barrales-Rienda, Influence of the swelling history on the swelling kinetics of stimuli-responsive poly[ $(\mathrm{N}$ isopropylacrylamide)-co-(methacrylic acid)] hydrogels, Polymer, 46(3) (2005) 685-693.

[35] A. S. Zdravković, L. B. Nikolić, S. S. Ilić-Stojanović, V. D. Nikolić, S. R. Savić, A. J. Kapor, The evaluation of temperature and $\mathrm{pH}$ influences on equilibrium swelling of poly(N-isopropylacrylamide-co-acrylic acid) hydrogels, Chemical Industry, (2017). doi:10.2298/ HEMIND161018001Z.

[36] N. A. Peppas, A. R. Khare, Preparation, structure and diffusional behavior of hydrogels in controlled release, Advanced Drug Delivery Reviews, 11(1-2) (1993) 1-35.

[37] A. R. Khare, N. A. Peppas, Swelling/deswelling of anionic copolymer gels, Biomaterials, 16(7) (1995) 559-567.

[38] S. P. Zhao, M. J. Cao, L. Y. Li, W. L. Xu, Synthesis and properties of biodegradable thermo- and $\mathrm{pH}$-sensitive poly[( $\mathrm{N}$-isopropylacrylamide)-co-(methacrylic acid)] hydrogels, Polymer Degradation and Stability, 95(5) (2010) 719-724.

[39] H. El-Hamshary, Synthesis and water sorption studies of $\mathrm{pH}$ sensitive poly(acrylamide-co-itaconic acid) hydrogels, European Polymer Journal, 43(11) (2007) 4830-4838.

[40] K. Kabiri, H. Omidian, M. J. Zohuriaan-Mehr, S. Doroudiani, Superabsorbent hydrogel composites and nanocomposites: A review, Polymer Composites, 32(2) (2011) 277-289.

[41] P. N. Dave, N. Subrahmanyam, S. Sharma, Kinetics and thermodynamics of copper ions removal from aqueous solution by use of activated charcoal, Indian Journal of Chemical Technology, 16(3) (2009) 234-239.

[42] A. Nilchi, T. S. Dehaghan, S. R. Garmarodi, Solid phase extraction of uranium and thorium on octadecyl bonded silica modified with Cyanex 302 from aqueous solutions, Journal of Radioanalytical and Nuclear Chemistry, 295(3) (2013) 2111-2115.

[43] K. R. Ramakrishna, T. Viraraghavan, Dye removal using low cost adsorbents, Water Science and Technology, 36(2-3) (1997) 189-196.
[44] P. B. Kelter, J. Grundman, D. S. Hage, J. D. Carr, C. M. Castro-Acuña, A Discussion of Water Pollution in the United States and Mexico; with High School Laboratory Activities for the Analysis of Lead, Atrazine, and Nitrate, Journal of Chemical Education, 74(12) (1997) 1413-1421.

[45] O. K. Júnior, L. V. A. Gurgel, R. P. de Freitas, L. F. Gil, Adsorption of $\mathrm{Cu}(\mathrm{II}), \mathrm{Cd}(\mathrm{II})$, and $\mathrm{Pb}(\mathrm{II})$ from aqueous single metal solutions by mercerized cellulose and mercerized sugarcane bagasse chemically modified with EDTA dianhydride (EDTAD), Carbohydrate Polymers, 77(3) (2009) 643-650.

[46] K. P. Singh, A. Malik, S. Sinha, Water quality assessment and apportionment of pollution sources of Gomti river (India) using multivariate statistical techniques- a case study, Analytica Chimica Acta, 538(1-2) (2005) 355-374.

[47] C. O'Neill, F. R. Hawkes, D. L. Hawkes, N. D. Lourenço, H. M. Pinheiro, W. Delée, Colour in textile effluents - sources, measurement, discharge contents and simulation: a review, Journal of Chemical Technology and Biotechnology, 74(11) (1999) 1009-1018.

[48] B. H. Hameed, A. T. M. Din, A. L. Ahmad, Adsorption of methylene blue onto bamboo-based activated carbon: kinetics and equilibrium studies, Journal of Hazardous Materials, 141(3) (2007) 819-825

[49] V. K. Jain, R. A. Pandya, S. G. Pillai, P. S. Shrivastav, Simultaneous preconcentration of uranium( $\mathrm{VI})$ and thorium(IV) from aqueous solutions using a chelating calix[4]arene anchored chloromethylated polystyrene solid phase, Talanta, 70(2) (2006) 257-266.

[50] Y. H. F. Al-qudah, G. A. Mahmoud, M. A. A. Khalek, Radiation crosslinked poly (vinyl alcohol)/acrylic acid copolymer for removal of heavy metal ions from aqueous solutions, Journal of Radiation Research and Applied Sciences, 7(2) (2014) 135-145.

[51] J. Wang, F. Liu, J. Wei, Enhanced adsorption properties of interpenetrating polymer network hydrogels for heavy metal ion removal, Polymer Bulletin, 67(8) (2011) 17091720.

[52] X. J. Ju, S. B. Zhang, M. Y. Zhou, R. Xie, L. Yang, L. Y. Chu, Novel heavy-metal adsorption material: ion-recognition P(NIPAM-co-BCAm) hydrogels for removal of lead(II) ions, Journal of Hazardous Materials, 167(1-3) (2009) 114-118.

[53] A. El Hag Ali, H. A. Shawky, H. A. Abd El Rehim, E. A. Hegazy, Synthesis and characterization of PVP/AAc copolymer hydrogel and its applications in the removal of heavy metals from aqueous solution, European Polymer Journal, 39(12) (2003) 2337-2344.

[54] A. Warshawasky, in lon exchange and sorption processes in hydrometallurgy, Critical Reports on Applied Chemistry, M. Streat, D. Naden Ed., John Wiley and Sons, New York 1987, p. 166.

[55] J. Cheng, G. Shan, P. Pan, Temperature and $\mathrm{pH}-$ dependent swelling and copper(II) adsorption of poly(Nisopropylacrylamide) copolymer hydrogel, RSC Advances, 5(76) (2015) 62091-62100.

[56] Q. Wu, P. Tian, Adsorption of Cu2+ ions with poly(Nisopropylacrylamide-co-methacrylic acid) micro/ nanoparticles, Journal of Applied Polymer Science, 109(6) (2008) 3470-3476.

[57] J. J. Chen, A. L. Ahmad, B. S. Ooi, Thermo-responsive properties of poly(N-isopropylacrylamide-co-acrylic acid) hydrogel and its effect on copper ion removal and fouling of polymer-enhanced ultrafiltration, Journal of Membrane Science, 469 (2014) 73-79. 
[58] H. Tokuyama, T. Iwama, Temperature-Swing SolidPhase Extraction of Heavy Metals on a Poly $(\mathrm{N}$ isopropylacrylamide) Hydrogel, Langmuir, 23(26) (2007) 13104-13108.

[59] H. Tokuyama, T. Iwama, Solid-phase extraction of indium(III) ions onto thermosensitive poly $(\mathrm{N}$ isopropylacrylamide), Separation and Purification Technology, 68(3) (2009) 417-421.

[60] B. Taşdelen, A. E. Osmanlioglu, E. Kam, The adsorption behavior of cesium on poly ( $\mathrm{N}$-isopropylacrylamide/ itaconic acid) copolymeric hydrogels, Polymer Bulletin, 70(11) (2013) 3041-3053.

[61] V. V. Panić, S. I. Šešlija, A. R. Nešić, S. J. Veličković, Adsorption of azo dyes on polymer materials, Chemical industry, 67(6) (2013) 881-900.

[62] D. Şolpan, S. Duran, M. Torun, Removal of cationic dyes by poly(acrylamide-co-acrylic acid) hydrogels in aqueous solutions, Radiation Physics and Chemistry, 77(4) (2008) 447-452.

[63] A. R. Nesic, V. V. Panic, A. E. Onjia, S. J. Velickovic, The enhanced removal of cationic dyes in binary system using novel copolymers with two kinds of acidic groups, Colloids and Surfaces A: Physicochemical and Engineering Aspects, 476 (2015) 24-34.

[64] D. D. Maksin, A. B. Nastasović, A. D. Milutinović-Nikolić, L. T. Suručić, Z. P. Sandić, R. V. Hercigonja, A. E. Onjia, Equilibrium and kinetics study on hexavalent chromium adsorption onto diethylene triamine grafted glycidyl methacrylate based copolymers, Journal of Hazardous Materials, 209-210 (2012) 99-110.

[65] G. S. Azhgozhinova, O. Guven, N. Pekel, A. V. Dubolazov, G. A. Mun, Z. S. Nurkeeva, Complex formation of linear poly(methacrylic acid) with uranyl ions in aqueous solutions, Journal of Colloid and Interface Science, 278(1) (2004) 155-159.

[66] F. An, X. Feng, B. Gao, Adsorption property and mechanism of composite adsorbent PMAA/SiO2 for aniline, Journal of Hazardous Materials, 178(1-3) (2010) 499-504.

[67] S. R. Shirsath, A. P. Patil, R. Patil, J. B. Naik, P. R. Gogate, S. H. Sonawane, Removal of Brilliant Green from wastewater using conventional and ultrasonically prepared poly(acrylic acid) hydrogel loaded with kaolin clay: A comparative study, Ultrasonics Sonochemistry, 20(3) (2013) 914-923.

[68] B. Taşdelen, D.'I. Çifçi, S. Meriç, Preparation of $\mathrm{N}$-isopropylacrylamide/itaconic acid/Pumice highly swollen composite hydrogels to explore their removal capacity of methylene blue, Colloids and Surfaces A: Physicochemical and Engineering Aspects, 519 (2017) 245-253.

[69] V. V. Panic, S. J. Velickovic, Removal of model cationic dye by adsorption onto poly(methacrylic acid)/zeolite hydrogel composites: Kinetics, equilibrium study and image analysis, Separation and Purification Technology, 122 (2014) 384-394.

[70] L. Aref, A. H. Navarchian, D. Dadkhah, Adsorption of crystal violet dye from aqueous solution by poly(acrylamide-comaleic acid)/montmorillonite nanocomposite, Journal of Polymers and the Environment, (2016). doi:10.1007/ s10924-016-0842-z.

[71] D. Parasuraman, A. K. Sarker, M. J. Serpe, Recyclability of poly ( $\mathrm{N}$-isopropylacrylamide) microgel-based assemblies for organic dye removal from water, Colloid and Polymer
Science, 291(8) (2013) 1795-1802.

[72] B. Taşdelen, A. E. Osmanlioglu, E. Kam, Cationic dye adsorption by poly( $\mathrm{N}$-isopropylacrylamide/maleic acid) copolymeric hydrogels prepared by gamma rays, Journal of Radioanalytical and Nuclear Chemistry, 298(3) (2013) 1469-1476.

[73] M. A. Corona-Rivera, V. M. Ovando-Medina, L. A. BernalJacome, E. Cervantes-González, I. D. Antonio-Carmona, N. E. Dávila-Guzmán, Remazol red dye removal using poly(acrylamide-co-acrylic acid) hydrogels and water absorbency studies, Colloid and Polymer Science, 295(1) (2017) 227-236.

[74] A. B. Fradj, R. Lafi, S. B. Hamouda, L. Gzara, A. H Hamzaoui, A. Hafiane, Effect of chemical parameters on the interaction between cationic dyes and poly(acrylic acid), Journal of Photochemistry and Photobiology A: Chemistry, 284 (2014) 49-54.

[75] S. Gadde, E. K. Batchelor, A. E. Kaifer, Controlling the Formation of Cyanine dye $\mathrm{H}$ - and J-Aggregates with Cucurbituril Hosts in the Presence of Anionic Polyelectrolytes, Chemistry - A European Journal, 15(24) (2009) 6025-6031.

[76] V. V. Panic, Z. P. Madzarevic, T. Volkov-Husovic, S. J. Velickovic, Poly(methacrylic acid) based hydrogels as sorbents for removal of cationic dye basic yellow 28: Kinetics, equilibrium study and image analysis, Chemical Engineering Journal, 217 (2013) 192-204.

[77] D. Parasuraman, M. J. Serpe, Poly (N-Isopropylacrylamide) Microgel-Based Assemblies for Organic Dye Removal from Water, ACS Applied Materials and Interfaces, 3(12) (2011) 4714-4721.

[78] D. Parasuraman, M. J. Serpe, Poly (N-Isopropylacrylamide) Microgels for Organic Dye Removal from Water, ACS Applied Materials and Interfaces, 3(7) (2011) 2732-2737.

[79] S. Q. Wang, Q. L. Liu, A. M. Zhu, Preparation of multisensitive poly ( $\mathrm{N}$-isopropylacrylamide-co-acrylic acid)/TiO2 composites for degradation of methyl orange, European Polymer Journal, 47(5) (2011) 1168-1175.

[80] S. K. Bajpai, M. Bhowmik, Poly(acrylamide-co-itaconic acid) as a Potential Ion-Exchange Sorbent for Effective Removal of Antibiotic Drug-Ciprofloxacin from Aqueous Solution, Journal of Macromolecular Science, Part A: Pure and Applied Chemistry, 48(2) (2010) 108-118.

[81] D. R. Kioussis, F. W. Wheaton, P. Kofinas, Phosphate binding polymeric hydrogels for aquaculture wastewater remediation, Aquacultural Engineering, 19(3) (1999) 163178.

[82] P. Kofinas, D. R. Kioussis, Reactive Phosphorus Removal from Aquaculture and Poultry Productions Systems Using Polymeric Hydrogels, Environmental Science and Technology, 37(2) (2003) 423-427.

[83] D. R. Kioussis, F. W. Wheaton, P. Kofinas, Reactive nitrogen and phosphorus removal from aquaculture wastewater effluents using polymer hydrogels, Aquacultural Engineering, 23(4) (2000) 315-332.

[84] S. A. Thompson, Water Use Management and Planning in the United States, Academic Press, New York, 1998, p. 371.

[85] A. Roy, S. K. Singh, J. Bajpai, A. K. Bajpai, Controlled pesticide release from biodegradable polymers, Central European Journal of Chemistry, 12(4) (2014) 453-469.

[86] M. Teodorescu, A. Lungu, P. O. Stanescu, C. Neamţu, Preparation and Properties of Novel Slow-Release NPK Agrochemical Formulations Based on Poly(acrylic 
acid) Hydrogels and Liquid Fertilizers, Industrial and Engineering Chemistry Research, 48(14) (2009) 65276534.

[87] D. Saraydin, E. Karadağ, O. Güven, The releases of agrochemicals from radiation induced acrylamide/crotonic acid hydrogels, Polymer Bulletin, 41(5) (1998) 577-584.

[88] D. Saraydin, E. Karadağ, O. Güven, Relationship between the swelling process and the releases of water soluble agrochemicals from radiation crosslinked acrylamide/ itaconic acid copolymers, Polymer Bulletin, 45(3) (2000) 287-294.

[89] R. Langer, N. A. Peppas, Chemical and Physical Structure of Polymers as Carriers for Controlled Release of Bioactive Agents: A Review, Journal of Macromolecular Science - Reviews in Macromolecular Chemistry and Physics, C23(1) (1983) 61-126.

[90] Y. Sun, Y. Ma, G. Fang, S. Ren, Y. Fu, Controlled Pesticide Release from Porous Composite Hydrogels Based on Lignin and Polyacrylic Acid, BioResources, 11(1) (2016) 2361-2371.

[91] R. Liang, H. Yuan, G. Xi, Q. Zhou, Synthesis of wheat straw-g-poly(acrylic acid) superabsorbent composites and release of urea from it, Carbohydrate Polymers, 77(2) (2009) 181-187.

[92] M. S. Mohy Eldin, H. M. El-Sherif, E. A. Soliman, A. A. Elzatahry, A. M. Omer, Polyacrylamide-Grafted Carboxymethyl Cellulose: Smart pH-Sensitive Hydrogel for Protein Concentration, Journal of Applied Polymer Science, 122(1) (2011) 469-479.

[93] E. Hernandez, I. Orozco-Avila, Temperature-Sensitive Hydrogels: A Gentle Way of Concentrating Cellulase Enzymes, Macromolecular Symposia, 283-284(1) (2009) 139-143.

[94] S. S. Ilić-Stojanović, L. B. Nikolić, V. D. Nikolić, J. R. Milić, S. D. Petrović, G. M. Nikolić, A. J. Kapor, Potential application of thermosensitive hydrogels for controlled release of phenacetin, Chemical Industry, 66(6) (2012) 831-839.
[95] S. S. Ilić-Stojanović, L. B. Nikolić, V. D. Nikolić, J. R. Milić, J. Stamenković, G. M. Nikolić, S. D. Petrović, Synthesis and characterization of thermosensitive hydrogels and the investigation of modified release of ibuprofen, Chemical Industry, 67(6) (2013) 901-912.

[96] S. S. Ilić-Stojanović, The synthesis and characterization of hydrogels based on $\mathrm{N}$-isopropylacrylamide and 2-hydroxypropyl methacrylate copolymers for potential use in the formulation with medicinal substances. PhD Thesis, Faculty of Technology, University of Niš, 2013.

[97] W. Xiong, W. Wang, Y. Wang, Y. Zhao, H. Chen, H. $\mathrm{Xu}, \mathrm{X}$. Yang, Dual temperature/pH-sensitive drug delivery of poly( $\mathrm{N}$-isopropylacrylamide-co-acrylic acid) nanogels conjugated with doxorubicin for potential application in tumor hyperthermia therapy, Colloids and Surfaces B: Biointerfaces, 84(2) (2011) 447-453.

[98] N. Z. Milašinović, N. B. Milosavljević, J. M. Filipović, Z. D. Knežević-Jugović, M. T. Kalagasidis Krušić, Immobilization of lipase from Candida rugosa into copolymer hydrogels of poly( $\mathrm{N}$-isopropylacrylamide-coitaconic acid) synthesized in the presence of surfactants, Chemical Industry, 65(6) (2011) 667-673.

[99] L. Nikolić, D. Skala, V. Nikolić, J. Stamenković, D. Babić, S. Ilić-Stojanović, Methyl methacrylate and acrylamide crosslinked macroporous copolymers, Journal of Applied Polymer Science, 91(1) (2004) 387-395.

[100] L. B. Nikolić, Povratno mešanje tečne faze i kinetika procesa alkoholne fermentacije u trofaznom bioreaktoru sa vibracionom mešalicom. Doktorska disertacija, Tehnološki fakultet u Leskovcu, Univerzitet u Nišu, 2003.

[101] J. Spasojević, A. Radosavljević, J. Krstić, D. Jovanović, V. Spasojević, M. Kalagasidis-Krušić, Z. Kačarević-Popović, Dual responsiveantibacterialAg-poly(N-isopropylacrylamide/ itaconic acid) hydrogel nanocomposites synthesized by gamma irradiation, European Polymer Journal, 69, (2015) 168-185.

Izvod

\section{PRIMENA HIDROGELOVA NA BAZI N-IZOPROPILAKRILAMIDA I ANJONSKIH KOMONOMERA}

Aleksandar S. Zdravković1 ${ }^{*}$, Ljubiša B. Nikolić², Snežana S. Ilić-Stojanović ${ }^{2}$ Vesna D. Nikolić ${ }^{2}$

(PREGLEDNI RAD) UDK 678.7:628.3:504.5

${ }^{1}$ Visoka tehnološko umetnička strukovna škola, Leskovac, Srbija

2Univerzitet u Nišu, Tehnološki fakultet, Leskovac, Srbija

Hidrogelovi predstavljaju trodimenzionalne mreže polimernih lanaca koje imaju sposobnost apsorpcije znatne količine vode ili biološkog fluida. Posebnu grupu hidrogelova predstavljaju kopolimeri koji reaguju na promene $\mathrm{pH}$ vrednosti i temperature. Poželjne karakteristike temperaturno- i pH-osetljivih hidrogelova na bazi $N$-izopropilakrilamida i anjonskih komonomera za različite primene, od farmaceutske do primene u zaštiti životne sredine, mogu se dizajnirati sastavom kopolimera. Prisustvo amidne i karboksilne grupe u strukturi ovih hidrogelova omogućava njihovu primenu kao adsorbenata u postupcima uklanjanja polutanata iz vodenih rastvora. Hidrogelovi na bazi $N$-izopropilakrilamida i anjonskih komonomera predstavljaju poželjne trodimenzionalne matrice za kontrolisano i produženo oslobađanje agrohemikalija i lekovitih supstanci u funkciji temperature i pH okolnog medijuma. Hidrogelovi kao separacioni uređaji vrše koncentrisanje rastvora jedinjenja ili mikroorganizama apsorpcijom većih količina vode. Metod imobilizacije enzima je još jedna primena ovih kopolimera.
Ključne reči: hidrogel, adsorpcija, polutanti, agrohemikalije, separacija, kontrolisana isporuka 